\title{
Molecular Characterization of some Date palms in Nigeria Using RAPD Markers
}

\author{
Beatrice O. Emoghene ${ }^{1}$, Omorefe Asemota ${ }^{1}$, MacDonald Idu ${ }^{2 *}$,Chukwuemeka R. Eke \\ ${ }^{1}$ Physiology Division, Nigerian Institute for Oil palm Research (NIFOR),PMB 1030, Benin City, Nigeria. \\ ${ }^{2}$ Plant Biology and Biotechnology Department, University of Benin, Benin City, Nigeria.
}

\section{ARTICLE INFO}

\section{Article history:}

Received on: 01/07/2015

Revised on: 22/07/2015

Accepted on: 24/08/2015

Available online: $22 / 10 / 2015$

Key words:

Date Palm, RAPD,

Molecular marker,

polymorphisms and

characterization.

\begin{abstract}
Date palm (Phoenix dactylifera L.) is a long-lived, dioecious, monocotyledonous fruit tree having $(2 \mathrm{n}=2 \mathrm{x}=36)$ chromosome number and wind pollinated member of the Arecaceae family. Identification of genetic variation and phylogenetic relationships in the date palm grown in Nigeria would be useful for genetic improvement and conservation. Genetic polymorphism in 10 date palms grown in Nigeria was analyzed using RAPD makers. The leaf samples for DNA extraction were collected from Nigerian Institute for Oil palm Research (NIFOR) date palm experimental substation Dutse, Jigawa State, Nigeria.DNA was extracted from young leaves for PCR Amplification employing DNeasy Mini Kit. Five RAPD selected primers were employed to determine genetic variation among the ten date palms genotypes and also to test the effectiveness of RAPD primers as a genetic maker. Polymorphism was observed among all the date palms using the RAPD primers. Cluster analysis using sequence alignment was done to generated dendrogram verifying relationship among the ten studied date palms, with an average similarity matrix range of 0.00 to 0.85 . This study has helped to design molecular markers such as RAPD that are suitable in the characterization of Nigerian date palm collection.
\end{abstract}

\section{INTRODUCTION}

Date palm (Phoenix dactylifera L.) is a long-lived, dioecious, monocotyledonous fruit tree having $(2 n=2 x=36)$ chromosome number and wind pollinated member of the Arecaceae family. It represents a source of income to oases inhabitants, provides protection to under crops from harsh climate and reduces damage from storms, wind and sand erosion. It is one of the oldest known fruit trees believed to have originated from Mesopotamia and cultivated for at least 5,000 years [1]. The tree plays an important role in the development of sustainable agriculture in many drought and saline affected regions of the world [2]. The numbers of known date palm cultivars that are distributed all over the world are approximately 5000 [3]. Date palms have always been clonally propagated to ensure the identity and uniformity of the cultivars. However, the existence of intra-cultivar variation could potentially cause confusion in cultivar nomenclature, preservation and utilization. Discrimination among closely related cultivars and clones is often extremely difficult. On the other hand the introduction of

* Corresponding Author

MacDonald Idu, Plant Biology and Biotechnology

Department, University of Benin, Benin City, Nigeria.

Email: mcdonald.idu@gmail.com
New genotypes from neighbouring countries together with traditional hand system of pollination may have lead to breeding recombinant genotypes and resulting in genetic variation of date palms in different geographical locations [1]. The correct identification of trees is not usually possible until the fruits are produced. Also, the characterization of cultivars and evaluation of genetic diversity require a large set of phenotypic data that are often difficult to assess and variable due to environmental influences [4].

Biochemical studies, including isozyme and activity analyses of peroxidases have been used to characterize date palms in Morocco and Tunisia. Such analysis doesn't reflect precisely polymorphisms may occur [3].

Also using morphological characteristic among cultivars that are closely related is not often reliable due to the influence of environmental conditions. Molecular biology techniques based on the polymerase chain reaction (PCR) offer a new tool for genetic analysis and construction of linkage maps. However, DNA fingerprinting has proven to be the most suitable method for identifying date palm cultivars accurately, analyzing their genetic diversity and phylogenetic relationships. DNA typing in plants is used primarily for identifying gene assortment, preservation of biodiversity or germplasm conservation and identifying markers associated with specific traits. 
Genetic preservation depends on the knowledge and distribution of the genetic diversity present in the existing germplasm [5, 1]. Worldwide, many markers have been used to identify among genotypes such as RAPD (Random Amplified Polymorphic DNA) is possibly the simplest test of all recently applied DNA-based tests for date palm identification [6]. The random amplified polymorphic DNA (RAPD) technique utilizes arbitrary primers for the amplification of genomic DNA, thus enabling identification of individual cultivars and differentiation of species. It is a PCR based marker technique, requiring only tiny amount of genomic DNA and does not require expensive material as in molecular biology techniques like blotting and radioactive material $[5,1]$.

RAPD markers have been used successfully for the analysis of cultivars and identification of species in most plants due to the simplicity and speed of the method. It can generate many useful genetic markers for the analysis of genetic diversity and phylogenetic relationships in closely related groups. DNA finger prints can be generated using short nucleotide sequences of primers (usually 10bp) and does not need any prior knowledge of sequence of DNA and reveals a high level of polymorphism. Hence, several researchers applied RAPD for the molecular characterization of date palm in Tunisia, Morocco, Saudi Arabia, Egypt and Algeria [7]. The authors proved the efficacy of RAPD markers for the estimation of phylogenetic relationships among date palm cultivars $[2,1,7]$. Soliman et al. [8] used RAPD-PCR to investigate the genetic similarity between male and female Egyptian date palm cultivars and identify unknown males of Egyptian date through known female cultivars using five primers [5]. To our knowledge, no research has been done to characterize date palm grown in Nigeria to analyze phylogenetic relationships. The objective of this work is to characterize some date palms grown in Nigeria using RAPD markers. This study will try to answer if there is similarity or diversity among the date palm.

\section{MATERIALS AND METHODS}

\subsection{Plant Material}

Ten randomly selected date palms grown at the NIFOR experimental date palm station Dutse, Jigawa State were used for this study.

\subsection{DNA extraction}

Leaves were collected from each date palm and then subjected to molecular analysis. Isolation protocol of the DNA was as follows: $200 \mathrm{mg}$ leaf sample was cut into small pieces and ground using liquid nitrogen to a fine powder, then the powder was transferred to an eppendorf tube. $400 \mu \mathrm{l}$ of buffer API and $4 \mu 1$ of RNase Stock solution $(100 \mathrm{mg} / \mathrm{ml})$ were added and vortexed vigorously. Mixture was incubated for $10 \mathrm{~min}$ at $65^{\circ} \mathrm{C}$ in a water bath and mixed 2-3 times during incubation by inverting tube. $130 \mu \mathrm{l}$ of buffer $\mathrm{AP}_{2}$ was added to the lysate, mixed and incubated for $5 \mathrm{~min}$ on ice. Lysate was applied to the QIA Shredder Spin column sitting in a $2 \mathrm{ml}$ collection tube and centrifuged for $2 \mathrm{~min}$ at maximum speed (10.000rpm). Supernatant was transferred to a new tube without disturbing the cell-debris pellet. $450 \mu \mathrm{l}$ of lysate was transferred to a fresh tube. Then, 0.5 volume of buffer $\mathrm{AP}_{3}$ and 1 volume of ethanol (96-100\%) were added to the cleared lysate and mixed by pipetting. $650 \mu \mathrm{l}$ of the mixture was transferred through DNeasy Mini spin column setting in a $2 \mathrm{ml}$ eppendorf collection tube. It was then centrifuged for $1 \mathrm{~min}$ at 8000rpm and flow-through was then discarded. DNeasy column was then placed in a new $2 \mathrm{ml}$ collection tube. $500 \mu \mathrm{l}$ buffer AW was added to the DNeasy column and centrifuged for $1 \mathrm{~min}$ at $8000 \mathrm{rpm}$. Then $500 \mu \mathrm{l}$ buffer AW was added to DNeasy column and centrifuged for $2 \mathrm{~min}$ at maximum speed (10000rpm) to dry the column membrane. DNeasy column was then transferred to a $1.5 \mathrm{ml}$ eppendorf tube and $100 \mu \mathrm{l}$ of preheated $\left(65^{\circ} \mathrm{C}\right)$ buffer $\mathrm{AE}$ was pipette on it to elute the bound DNA directly out from the DNeasy column membrane. It was then incubated for $5 \mathrm{~min}$ at room temperature and centrifuged for $1 \mathrm{~min}$ at $800 \mathrm{rpm}$ to elute the DNA. The DNA was stored at $4^{\circ} \mathrm{C}$ for further use. Five RAPD primers (successfully utilized in other plant species) were used for RAPD-PCR analysis. This was performed in order to test their readability and amplification profile for polymorphism. The polymerase chain reaction (PCR) mixture was performed in $30 \mu \mathrm{l}$ volume containing $2.5 \mathrm{mM}$ dNTPs, $25 \mathrm{mM} \mathrm{MgCl}, 10 \mathrm{x}$ buffer, 10pmol primer, $1 \mu 1$ Taq DNA Polymerase (Bioron, Germany) and 25ng genomic DNA. All reactions were performed in an automated thermal cycler (Model Techne512). RAPD-PCR program included an initial denaturation step at $94^{\circ} \mathrm{C}$ for $4 \mathrm{~min}$ followed by 45 cycles with $94^{\circ} \mathrm{C}$ for $1 \mathrm{~min}$ for DNA denaturation, $37^{\circ} \mathrm{C}$ for $1 \mathrm{~min}$ for annealing, for each primer, extension at $72^{\circ} \mathrm{C}$ for $10 \mathrm{~min}$. The amplified DNA fragments were separated on $1.5 \%$ agarose gel stained with ethidium bromide. The gel ran at $80 \mathrm{~V}$ for $30 \mathrm{~min}$ and fragments sizes were estimated with 100bp ladder marker. The amplified product was visualized on an ultra-violet light transilluminator and photographed using UVP gel documentation system. A negative control reaction without DNA template was also included.

\subsection{Data Analysis}

The DNA bands generated by each primer were counted and their molecular sizes were compared with those of the DNA markers. The bands scored from DNA profiles generated by each primer were pooled together. Then the presence or absence of each DNA band was treated as a binary character in a data matrix (coded 1 and 0, respectively) on Gel Documentation System (BioRad).

\section{RESULTS AND DISCUSSION}

According to documented publications, this is the first report on molecular analysis using RAPD primers on characterization of date palm in Nigeria. In this research, RAPD markers were used to determine genetic variation within available germplasm. PCR analysis showed that the selected five RAPD primers produced polymorphic bands which could be scored 
unambiguously. The results from our work proved that RAPD primers are useful tools for genetic variation study in date palm. In this present study, the pedigree (parentage) of date palm grown in Nigeria and their cultivars is not known. Most of the date palms grown are as a result of selection by the date palm growers. The relative genetic variation of date palm can be done using different methods such as biochemical, morphological and molecular markers.

The five RAPD primers yielded 320 scorable bands (with an average of 64 bands per primer), including twenty-five polymorphic bands $(7.81 \%)$ and fifteen monomorphic bands $(4.69 \%)$. The number of bands from each primer varied from 4486 bands. A low level of polymorphism was generated utilizing the five RAPD-PCR primers (Plates 1a - e and Tables1, 2,). Primer OP-A07 gave the highest polymorphism $(91.66 \%)$ followed by primer OP-A09 $(88.33 \%)$ while primer OP-C04 gave the lowest polymorphism $(20 \%)$. The highest amplicons was generated fromRCP1 (tissue culture generated 35 amplicons), followed by R5P7 and P6P8 (34 amplicons), while R8P6 generated the lowest (28 amplicons). Primer OP-B04 generated the highest amplicons (86 amplicons) while primer OP-C04 had the lowest (44 amplicons). The highest numbers of bands were scored for primer OP-A07 (twelve bands) followed by primers OP-B04 (nine bands), OP-B09 (eight bands), OP-A09 (six bands) and OPC04 (five bands) (Tables1, 2).

Table 1: Number of amplified fragments markers of ten date palm cultivars based on RAPD - PCR analysis

\begin{tabular}{|c|c|c|c|c|c|c|c|}
\hline & & & RAPD & Primers & & & \\
\hline Date palm cultivars & ڤ̆ & $\begin{array}{l}5 \\
\vdots \\
0 \\
0\end{array}$ & 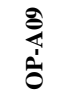 & 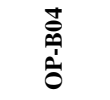 & $\begin{array}{l}\hat{\hat{े}} \\
\hat{a} \\
\hat{0}\end{array}$ & 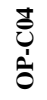 & 吾 \\
\hline RCP1 & $\mathrm{F}$ & 8 & 6 & 9 & 7 & 5 & 35 \\
\hline Medjoole & ND & 7 & 6 & 9 & 7 & 4 & 33 \\
\hline $\mathrm{R} 4 \mathrm{P} 2$ & $\mathrm{~F}$ & 9 & 6 & 6 & 6 & 4 & 31 \\
\hline R5P7 & $\mathrm{F}$ & 8 & 6 & 9 & 6 & 5 & 34 \\
\hline R6P8 & $\mathrm{M}$ & 8 & 6 & 9 & 6 & 5 & 34 \\
\hline R7P6 & M & 7 & 6 & 9 & 6 & 5 & 33 \\
\hline R8P1 & $\mathrm{F}$ & 7 & 6 & 8 & 5 & 4 & 30 \\
\hline R8P4 & M & 9 & 5 & 9 & 6 & 4 & 33 \\
\hline R8P6 & $\mathrm{F}$ & 9 & 1 & 9 & 5 & 4 & 28 \\
\hline R8P13 & M & 9 & 1 & 9 & 6 & 4 & 29 \\
\hline TAF & & 81 & 49 & 86 & 60 & 44 & 320 \\
\hline PB & & 11 & 5 & 4 & 4 & 1 & 25 \\
\hline $\mathrm{MB}$ & & 1 & 1 & 5 & 4 & 4 & 15 \\
\hline $\begin{array}{l}\text { TAF }=\text { To } \\
\mathrm{PB}=\text { Poly } \\
\mathrm{MB}=\text { Mor } \\
\text { ND = Not }\end{array}$ & phic & b & fiec & $\begin{array}{l}\text { gments } \\
=\text { Male }\end{array}$ & & & \\
\hline
\end{tabular}

All RAPD-PCR primers used in the present study allowed for enough distinction among RCP1(tissue culture generated), Medjoole ,R4P2, R5P7 , R6P8, R7P6 , R8P1, R8P4, R8P6 and R8P13 date palms (Figure 1).In the phylogenetic relationship between the date palms using RAPD linkage, it was discovered that R8P6 is delimited from the rest of the date palms at a distance of 25.0. On the other hand,R4P2 was separated at a distance of 18.0 with R7P6 separated with two sub-groups at a distance of 14.0 while R6P8 in one sub-group with a distance of
11.0. RCP1 and R8P4 showed a genetic relationship (similarity) at a distance of 8.0 with R5P7 and R7P6 also showed a genetic similarity at a distance of 5.0. R8P6 and R8P13 are closely related at a distance of 2.0. RCP1, Medjoole,R5P7andR8P7 are closely related at the same distance of 1.0 (Figure 1).

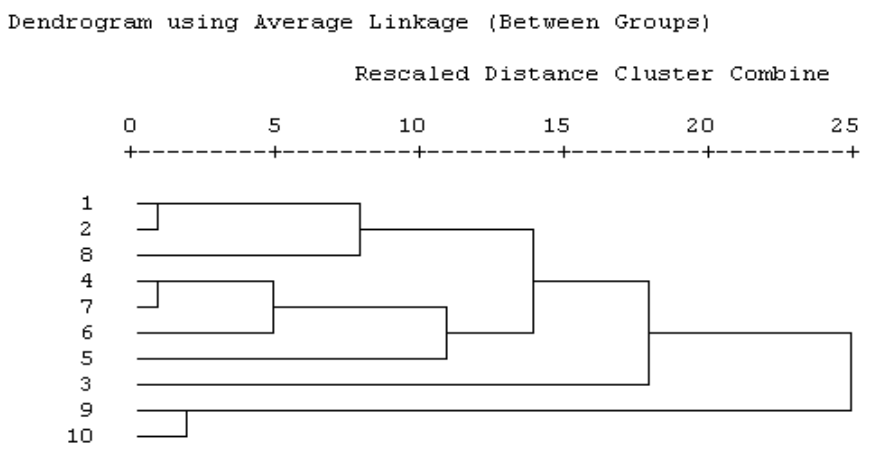

Fig. 1: Dendrogram of nine Nigerian and one foreign date palm cultivars based on Dice genetic similarity coefficient using RAPD data.

It can be seen from the dendogram analysis that there is linkage between the date palms that by using RAPD, RCP1, Medjoole, R5P7 and R8P7 are same date palms suggesting that they are Medjoole cultivars (Figure 1, Table3).Over all comparison among the date palms across the five RAPD primers revealed the power of RAPD in distinguishing among date palm cultivars grown in the same location (Figure 1, Table 3).

Table 2: RAPD - PCR amplification products of DNA extracted from leaves of ten date palm cultivars using five random primers.

\begin{tabular}{|c|c|c|c|c|c|c|}
\hline 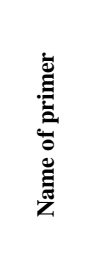 & 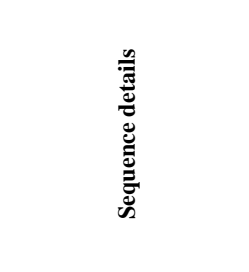 & 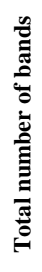 & 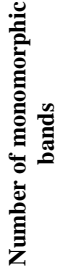 & 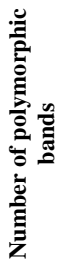 & 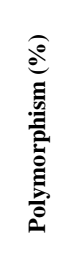 & 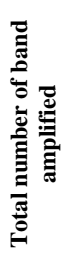 \\
\hline OP-A07 & $5^{1}$ GAA ACG GGT G $3^{1}$ & 12 & 1 & 11 & 91.66 & 81 \\
\hline OP-A09 & $5^{1}$ GGG TAA CGC C $3^{1}$ & 6 & 1 & 5 & 83.33 & 49 \\
\hline OP-B04 & $5^{1}$ TGC GCC CTT C $3^{1}$ & 9 & 5 & 4 & 44.44 & 86 \\
\hline OP-B09 & $5^{1}$ TGG GGG ACT C $3^{1}$ & 8 & 4 & 4 & 50.00 & 60 \\
\hline $\mathrm{OP}-\mathrm{C} 04$ & $5^{1}$ GAT GAC CGC C $3^{1}$ & 5 & 4 & 1 & 20.00 & 44 \\
\hline Total & & 40 & 15 & 25 & 289.43 & 320 \\
\hline Mean & & & & & 57.89 & \\
\hline
\end{tabular}

Table 3: Similarity Matrix of RAPD.

\begin{tabular}{lllllllllll}
\hline & $\mathbf{1}$ & $\mathbf{2}$ & $\mathbf{3}$ & $\mathbf{4}$ & $\mathbf{5}$ & $\mathbf{6}$ & $\mathbf{7}$ & $\mathbf{8}$ & $\mathbf{9}$ & $\mathbf{1 0}$ \\
\hline $\mathbf{1}$ & $\mathbf{1 . 0 0}$ & & & & & & & & & \\
$\mathbf{2}$ & $\mathbf{0 . 0}$ & $\mathbf{1 . 0 0}$ & & & & & & & & \\
$\mathbf{3}$ & $\mathbf{0 . 4 9}$ & $\mathbf{0 . 5 7}$ & $\mathbf{1 . 0 0}$ & & & & & & & \\
$\mathbf{4}$ & $\mathbf{0 . 2 5}$ & $\mathbf{0 . 4 5}$ & 0.29 & $\mathbf{1 . 0 0}$ & & & & & & \\
$\mathbf{5}$ & $\mathbf{0 . 3 4}$ & $\mathbf{0 . 2 8}$ & 0.82 & $\mathbf{0 . 2 8}$ & $\mathbf{1 . 0 0}$ & & & & & \\
$\mathbf{6}$ & $\mathbf{0 . 3 2}$ & $\mathbf{0 . 4 0}$ & 0.51 & $\mathbf{0 . 1 3}$ & $\mathbf{0 . 2 2}$ & $\mathbf{1 . 0 0}$ & & & & \\
$\mathbf{7}$ & $\mathbf{0 . 4 9}$ & $\mathbf{0 . 5 7}$ & 0.41 & $\mathbf{0 . 0 2}$ & $\mathbf{0 . 3 9}$ & $\mathbf{0 . 0 9}$ & $\mathbf{1 . 0 0}$ & & & \\
$\mathbf{8}$ & $\mathbf{0 . 2 5}$ & $\mathbf{0 . 1 9}$ & 0.43 & $\mathbf{0 . 3 2}$ & $\mathbf{0 . 5 5}$ & $\mathbf{0 . 1 3}$ & $\mathbf{0 . 2 9}$ & $\mathbf{1 . 0 0}$ & & \\
$\mathbf{9}$ & $\mathbf{0 . 7 6}$ & $\mathbf{0 . 5 7}$ & 1.00 & $\mathbf{0 . 8 4}$ & $\mathbf{0 . 8 2}$ & $\mathbf{0 . 7 9}$ & $\mathbf{0 . 8 5}$ & $\mathbf{0 . 2 9}$ & $\mathbf{1 . 0 0}$ & \\
$\mathbf{1 0}$ & $\mathbf{0 . 6 8}$ & $\mathbf{0 . 6 3}$ & 0.76 & $\mathbf{0 . 6 3}$ & $\mathbf{0 . 1 3}$ & $\mathbf{0 . 8 4}$ & $\mathbf{0 . 7 6}$ & $\mathbf{0 . 3 5}$ & $\mathbf{0 . 4 3}$ & $\mathbf{1 . 0}$ \\
\hline
\end{tabular}

Genetic similarity was scored between the ten date palms using RAPD profiles for each of the five RAPD primers and calculating the coefficient of genetic similarity (Tables 3 ), the average similarity matrix ranged from 0.00 to 0.85 . From the 
results, the date palms studied were closely related at the DNA level. The highest similarity coefficient value $(0.85)$ was observed between R7P6 and R8P1which seem to be the nearest two varieties and can be closely regrouped. The similarity coefficient value of 0.00 was obtained between Medjoole, and RCP1indicating that these were among themselves similar but distinct from the other date palms. All the other date palms displayed high level of similarity.

Genomic DNA extracted from 10 randomly selected Nigerian date palms was successfully amplified and resulted in scorable RAPD profiles. Successful amplification was observed using the RAPD primer pairs and data were useful. Through the technique of RAPD, which requires small amount of DNA it was possible to identify markers that generated polymorphic bands among the studied date palms. The use of RAPD has been demonstrated to have several advantages over other techniques of DNA finger printing [9]. In contrast with other molecular techniques such as SNPs (Simple Nucleotide Polymorphisms), SSRs (Simple Sequence Repeats), RFLP, DNA sequencing and allozymes, the RAPD technique is very simple to carry out and does not require previous knowledge of the genome in study. This is a rapid method that is financially and technically less demanding compared to the AFLP method and could be more useful for routine germplasm screening. It is used for examination of a large number of loci and primers are made on aleatory sequences. Despite its advantages this technique has a problem of reproducibility [9]. Nearly all RAPD markers are dominant. Band of identical size amplified with the same primer are considered to be at the same locus consisting of two alleles [9]. The present study used RAPD primers to distinguish and develop molecular markers for the various Nigerian date palms. The Nigerian date palm germplasm has not yet been subjected to detailed molecular characterizations to develop useable markers. The use of markers characterization in the date palm allows rapid, detailed information on the genetic diversity of a population. The results of this study showed clear and high yields of amplified DNA fragments. RAPD appears to be a powerful technique for the analysis of genetic diversity of date palm germplasm. And our result is in support with Sonboli et al. and Eissa et al., $[10,11]$ that RAPD marker are reliable for identification of date palm cultivars and it also reveals high levels of polymorphism among species indicating its effectiveness for evaluating intra and inter-specific genetic diversity in the genus. Clear amplified polymorphic DNA products were obtained from the 5 different RAPD primers used for screening and developing molecular markers among the 10 randomly selected date palms. All the 10 date palms revealed a unique profile with 5 RAPD primers. Different primers produced different levels of polymorphism among the different cultivars (Plates 1a-e). Askari et al. [12] in their study of molecular phylogeny of seven date palm cultivars by DNA fingerprinting reported that different primers produced different levels of polymorphism among the different cultivars they studied. Adawy et al. and Hussein et al. [13, 14] reported low RAPD and ISSR polymorphism in Egyptian date palm cultivars whereas Moghaieb et al. (2010) [15] reported relatively high RAPD and ISSR polymorphism. RAPD markers are dominant molecular markers and RAPD markers showed a higher mean value for the number of cultivars studied.
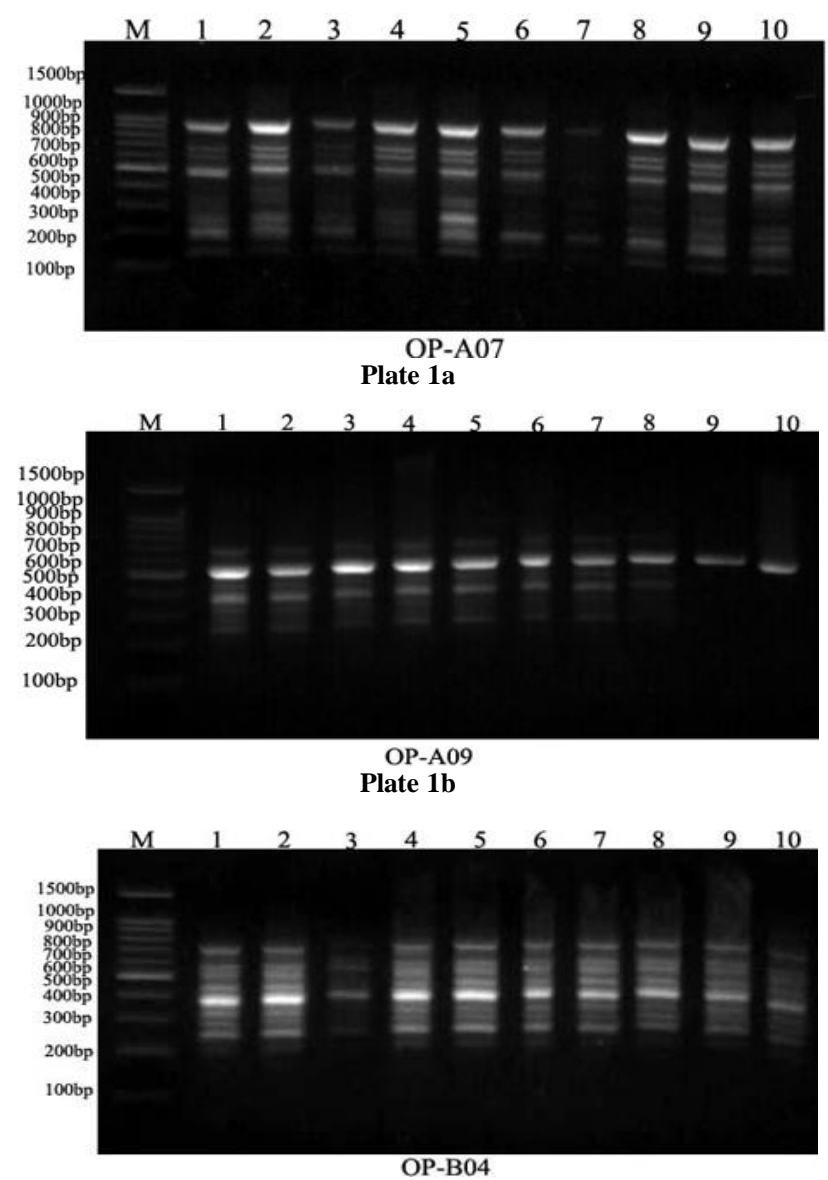

Plate 1c
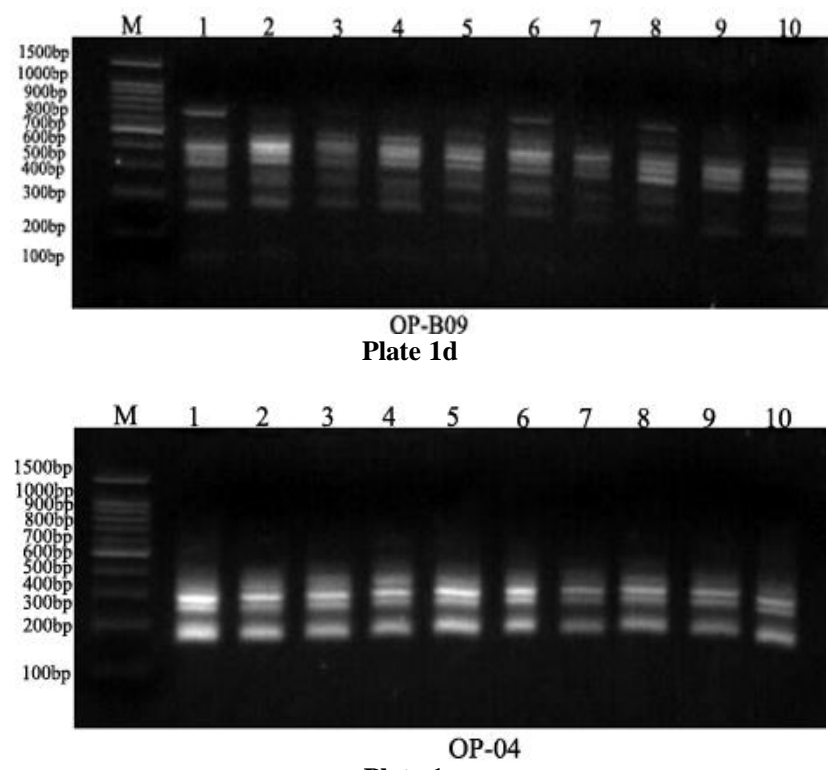

Plate 1e

Plates. 1a - e: RAPD profile of ten date palm grown in Nigeria amplified with five different RAPD primers. M: $100 \mathrm{bp}$ ladder marker. Lanes 1 through 10 refer to the different date palm: RCP1, Medjoole, R4P2, R5P7, R6P8, R7P6, R8P1, R8P4, R8P6 and R8P13. 
Some of the cultivars are closely related to each other and they have similar bands patterns but in addition, have one or more bands that differentiate between them using the different RAPD primers. A similar result was reported by Bekheet et al. [16] in their study on biochemical and molecular approaches to sex determination in date palm.

Askari et al. [12] in their study molecular phylogeny of seven date palm cultivars by DNA finger printing also reported that RAPD primer appeared to be effective for the identification of date palm varieties, although polymorphism was low when compared with other cultivated species. For reproducibility and reliability of the RAPD markers, PCR amplifications were conducted twice with each primer. This study represents the first attempt to use RAPD markers to differentiate date palms grown in Nigeria. The Dice similarity coefficient matrix was computed to cluster the data and draw the precise relationships among the ten studied date palm genotypes.

The Dendogram shown in Figure 1 illustrates the phylogenetic relationship between the studied date palms. R4P2 was in a very distinct group compared to the rest date palms. RCP1 and Medjoole were closely related to each other which suggest that they could be considered one cultivar. R7P6 - R8P1, R8P4 and R8P6 may constitute paired clusters (Figure 1). The lowest similarity (0.00) was recorded between medjoole and RCP1 while the highest similarity $(0.85)$ was recorded between R4P2 and R8P6. The RAPD marker showed highest genetic similarity between RCP1 and medjoole date palms while highest genetic distance of these date palms with R4P2 and R8P6. Moreover, the polymorphism detected and its reproducibility suggests that RAPD markers are reliable for characterization of date palm cultivars in Nigeria. RAPD too lis very important for molecular characterization. The observations and interpretations of the current investigation are interesting as a preliminary exploration and analysis to determine genetic relationships in date palm grown in Nigeria.

\section{CONCLUSION}

The five RAPD primers used for this research produced polymorphic and unambiguously bands. RAPD method therefore, is an alternative strategy to precisely access the phylogenetic relationship between sets of Nigerian date palm varieties. It is obviously necessary to enlarge both the number of varieties and primers to obtain a deeper insight into Nigerian date palm varieties.

\section{ACKNOWLEDGMENTS}

The authors are grateful to the Nigerian Institute for Oil Palm Research and the Department of Plant Biology and Biotechnology, University of Benin as well as the staff of Physiology Division, NIFOR for supporting and providing facilities used for this research.

\section{REFERENCES}

1. Mirbahar AA, Markhand GS, Khan S, Abul-Soad AA. Molecular characterization of some Pakistani Date Palm (Phoenix dactilyfera L.) cultivars by RAPD markers. Pakistan Journal of Botany. 2014; 46(2): 619-625.

2. Khierallah HSM, Hussien NH. The role of coconut water and caseinhydrolysate in somatic embryogenesis of date palm and genetic stability detection using RAPD markers. Research in Biotechnology. 2013; 4(3):20-28.

3. Khierallah HSM, Al-Sammarraie SKI, Mohammed HI. Molecular characterization of some Iraqi Date Palm cultivars using RAPD and ISSR markers. Journal of Asian Scientific Research. 2014; 4(9):490-503.

4. El-Rayes DA. Characterization of three date palm cultivars based on RAPD fingerprints and fruit chemical composition. JKAU: Met., Env. \& Arid Land Agric. Sci.2009;20(2):3-20.

5. Saker MM, Hassan WM, Zeid IMA, Hassan AE, Bas AE. The Application of Random Amplified Polymorphic DNA (RAPD) in the classification of Egyptian Date Palm (Phoenix dactilyfera L) cultivars. Journal of American Science.2012; 8(1):152-159.

6. Ibrahim IA, Hashem MH, Hemeida AA, Hassan MM, Maksoud AIA.Characterization of genetic diversity of Date palm (Phoenix dactylifera L.)cultivars collected from New valley governorate (ElKharga and Dakhleh) based onMorphological variability and molecular markers.Life Science Journal.2014; 11 (11):879-889.

7. Haider N, Nabulsi I, MirAli N. Phylogenetic relationships among date palm(Phoenix dactylifera L.) cultivars in Syria using RAPD and ISSR markers. Journal of Plant Biology Research.2012; 1(2):12-24.

8. Soliman SS, Ali BA, Ahmen MMM. Genetics Comparisons of Egyptian Date Palm Cultivars (Phoenix dactylifera L.) by RAPD-PCR. African Journal of Biotechnology. 2003; 2 (4): 86-87.

9. Nazari L, Pakniyat H. Genetic diversity of wild and cultivated barley genotypes under drought stress using RAPD markers. Biotechnology. 2008;7(4): $745-750$.

10. Sonboli A, Gholipour A, Mirjalili MH, Rad MA. Molecular characterization of Iranian Dracocephalum (Lamiaceae) species based on RAPD data. Acta Biologica Szegediensis. 2011; 55(20):227-230.

11. Eissa EA, El-Razek ABA, El-Sharabasy SF, Rizk RM. Morphological and molecular genetic characterization of soft date palm (Phoenix dactylifera L.) cultivars in Egypt. Egypt. J. Genet. Cytol.2009;38:269284.

12. Askari E, Al-Khalifah NS, Ohmura T, Al-Hafedh YS, Khan FA, Al-Hindi A, Okawara R. Molecular phylogeny of seven date palm (Phoenix dactylifera L.) cultivars by DNA fingerprinting. Pakistan Journal of Botany. 2003; 35(3): 323 - 330 .

13. Adawy SS, Hussein EHA, El-Khishin D, Saker MM, Mohamed AA, ElItriby HA. Genotyping Egyptian date palm cultivars using RAPD, ISSR, AFLP markers and estimation of genetic stability among tissue culture derived plants. Arab Journal of Biotechnology. 2004; 8(1): $99-114$.

14. Hussein EHA, Adawy SS, Ismai SEM, El-Itriby HA. Molecular characterization of some Egyptian date palm germplasm using RAPD and ISSR markers. Arab Journal of Biotechnology.2004; 8(1): 83 - 98.

15. Moghaieb REA, Abdel-Hadi AA, Ahmed MRA, Hassan AGM. Genetic diversity and sex determination in date palms (Phoenix dactylifera $\mathrm{L}$.) based on DNA markers. Arab Journal of Biotechnology. 2010;13(2): 143 $-156$.

16. Bekheet SA, Solliman ME, Taha HS. In vitro differentiation of zygotic lines of date palm: Biochemical and molecular approaches to sex determination. Proceedings of $3^{\text {rd }}$ International conference on date palm. Abu Dhabi, UAE.2007; Pp 117 - 125.

\section{How to cite this article:}

Beatrice Emoghene, Omorefe Asemota, MacDonald Idu, Chukwuemeka Eke. Molecular Characterization of some Date palms in Nigeria Using Rapd Markers. J App Biol Biotech. 2015; 3 (05): 026-030. DOI: 10.7324/JABB.2015.3505 